\title{
Pelatihan dan Pendampingan Peningkatan Keahlihan Modelling Character 3D untuk Siswa dan Guru di SMK ST. FRANSISKUS SEMARANG
}

\author{
Muslih $^{1}$, Ajib Susanto ${ }^{2}$, Ali Muqoddas ${ }^{3}$, Elkaf Rahmawan Pramudya ${ }^{4}$, M. Arief Soeleman ${ }^{5}$ \\ ${ }_{1,2,4,5}$ Teknik Informatika, Fakultas Ilmu Komputer, Universitas Dian Nuswantoro Semarang \\ ${ }^{3}$ Desain Komunikasi Visual, Fakultas Ilmu Komputer, Universitas Dian Nuswantoro Semarang \\ E-mail: ${ }^{1}$ muslih@dsn.dinus.ac.id, ${ }^{2}$ ajib.susanto@dsn.dinus.ac.id, ${ }^{3}$ alimuqoddas@dsn.dinus.ac.id, \\ elkaf.rahmawan@dsn.dinus.ac.id, ${ }^{5}$ m.arief.soeleman@dsn.dinus.ac.id
}

\begin{abstract}
Abstrak
Perkembangan saat ini teknologi informasi dan komunikasi (TIK) berjalan sangat begitu cepat yang diiringi dengan perkembangan bidang lainnya seperti teknologi telekomunikasi, termasuk juga pada jaringan komputer dan aplikasi 3D, seperti saat ini yang sedang ada wabah virus Corona (Covid-19) informasi dengan 3D sangatlah membantu. Kurikulum di SMK dengan DUDI (dunia usaha dan industri) diselaraskan agar lulusan SMK dapat siap pakai dengan lapangan pekerjaan yang tersedia. Tujuan pelatihan dan pendampingan agar Guru dan siswa dapat meningkatkan keahlian modelling character 3D di lingkungan Sekolah Menengah Kejuruan (SMK) ST. Fransikus Semarang. Implementasi kegiatan dengan melakukan pelatihan dan pendampingan melalui virtual secara bertahap dengan memberikan contoh dana penugasan modelling character 3D sehingga hasil karya multimedia lebih interaktif dan menarik.
\end{abstract}

Kata kunci: Pemodelan Karakter 3D, Guru, Siswa, Pelatihan, Pendampingan

\begin{abstract}
Current developments Information and Communication Technology (ICT) is running very fast, accompanied by developments in other fields such as telecommunications technology, including computer networks and $3 D$ applications, such as the current outbreak of the Corona virus (Covid-19), information in 3D is very help. The curriculum in SMK with DUDI (business and industry) is aligned so that SMK graduates can be ready to use the available job opportunities. The purpose of training and mentoring is so that teachers and students can improve their $3 D$ character modeling skills in the ST Vocational High School (SMK) ST. Francis Semarang. Implementation of activities by conducting training and mentoring through virtual in stages by providing examples of $3 D$ character modeling assignments so that multimedia works are more interactive and interesting.
\end{abstract}

Keywords: 3D Character Modeling, Teachers, Students, Training, Mentoring

\section{PENDAHULUAN}

Sekolah Menengah Kejuruan (SMK) ditetapkan oleh Pemerintah sebagai Pendidikan Vokasi dasar pengelolaan SMK, pendidikan Vokasi bertujuan dalam peningkatkan kualitas dari sumber daya manusia dan terhadap daya saing bangsa di masa yang akan datang, sebagaimana disampaikan oleh Gubernur Jawa Tengah[1] sehingga Provinsi Jawa Tengah sangat berharap tinggi dari lulusan SMK. Pemerintah Propinsi Jawa Tengah menyelaraskan kurikulum di SMK dengan DUDI (dunia usaha dan industri) agar lulusan SMK dapat siap pakai dengan lapangan pekerjaan yang tersedia. 
Sejarah pendidikan menunjukkan bahwa guru adalah satu-satunya sumber dalam memperoleh pelajaran. Kemudian berkembang, bahwa sumber belajar bertambah yaitu adanya sumber dari buku. Orang yang tercatat sebagai penulis bu yang pertama adalah Johan Amos Comenius berupa buku bergambar untuk anak sekolah. Dengan judul buku "Orbis Sensualium Pictus" (Dunia Tergambar) pertama kali diterbitkan di tahun 1657. Penulisan buku ini dilandasi pada suatu konsep dasar yaitu tidak ada sesuatu di dalam akal pikiran manusia, kecuali didahului oleh penginderaan. Sehingga dari sini para pendidik menyadari mulai perlunya sarana untuk belajar yang mampu memberikan rangsangan dan pengalaman dari belajar secara menyeluruh untuk siswa melalui perantara semua indera, terutama dengan indera pandang dan dengar[2].

Perkembangan saat ini Information and Communication Technology (ICT) atau Teknologi Informasi dan Komunikasi (TIK) berjalan sangat begitu cepat yang diiringi dengan perkembangan bidang lainnya seperti teknologi telekomunikasi, termasuk juga pada jaringan komputer dan aplikasi 3D, seperti saat ini yang sedang ada wabah virus Corona (Covid-19) untuk memberikan informasi masyarakat dunia sebuah situs https://covidvisualizer.com/[3] membuat tampilan awal web berupa globe $3 D$ sehinggga pengunjung dapat melihat perkembangan kasus Covid-19 tiap negara dengan hanya meng-klik posisi peta suatu negara.

Dalam menyikapi kemajuan dan perkembangan ICT tersebut, para guru dituntut untuk meningkatkan kemampuan dibidang teknologi (ICT) agar supaya mampu mengembangkan materi-materi yang disampaikan saat pembelajaran menggunakan ICT dan memanfaatkan ICT untuk media pembelajaran. Bertujuan untuk memberikan kesempatan dan kemudahan yang seluas-luasnya kepada pembelajar dalam proses belajar termasuk perkembangan $3 \mathrm{D}[4]$ dimana perkembangannya sudah dari tahun sebelum masehi, kemudian berkembang menjadi animasi 2D yang merasakan keberhasilannya diantaranya adalah Seven Dwarfs (1937) dan Fantasia (1940) dari Walt Disney[4].

Berdasarkan hasil penelitian SMK di Salatiga [5] bahwa SMK memberikan sumbangan tenaga kerja yang cukup besar, akan tetapi sekitar 12\% lulusan SMK masih penganggur menunggu pekerjaan. Berdasarkan hasil data Vocational Education Policy : White Paper tahun 2019 menunjukkan tingkat pengangguran terbuka (TPT) dari lulusan SMK menjadi tertinggi jika dibandingkan dengan lulusan lainnya[6], sehingga pihak SMK bekerjasama dengan Pemerintah Provinsi dan dunia usaha dan industry (DUDI)[7] juga harus membantu memberikan keterampilan lebih kepada para lulusannya.

SMK ST. Fransiskus Semarang sebagai instansi Pendidikan tentunya mempunyai tugas salah satunya adalah memberikan pelatihan peningkatan kemampuan bagi guru dalam penggunaan teknologi informasi komputer dalam upaya peningkatan kemampuan membuat bahan ajar berbasis multimedia dalam proses belajar mengajar di kelas. Untuk para siswa juga perlu dibekali kemampuan yang lebih dari lulusan lainnya salah satunya adalah keterampilan di dunia 3D. Berbagai kendala yang dihadapi selain kurang tercukupinya anggaran yang disediakan oleh sekolah untuk meningkatkan kemampuan dengan mengikuti pelatihan dan sekolah lagi, juga kurangnya tenaga yang memberikan pelatihan pembuatan karya 3D, sebagaimana hasil wawancara singkat dengan guru dan para siswa sehingga mengharapkan ada materi pelatihan khusus 3D yaitu pembuatan modelling character $3 D$ sehingga hasil karya multimedia lebih interaktif dan menarik.

Pada pengabdian masyarakat ini diusulkan untuk kegiatan pelatihan dengan melalui media daring dengan menggunakan Zoom Meeting, dilakukan selama 5 kali pertemuan dan diakhir sesi diberikan tugas untuk mengetahui hasil penyerapan materi yang sudah disampaikan. Hasil pelatihan terlaksana dengan baik dan masing-masing peserta menghasilkan karya sudah sesuai target yang diinginkan dari pelatihan ini sehingga diharapkan terutama siswa Kelas XII sudah siap dalam mengikuti ujian kompetensi kemampuan (UKK)[8] tahun pelajaran 2020/2021 sebelum lulus dari SMK. 


\section{METODE}

Tahapan metode pelatihan dan pendampingan materi modelling karakter 3D untuk siswa dan guru menggunakan tahapan dari model Plan, Do, Check and Act $(P D C A)[9][10][11]$ yang merupakan suatu proses berkelanjutan untuk melakukan koreksi dan perbaikan sistem lanjutannya, dimana tahapan-tahapan dapat dijelaskanseperti berikut :

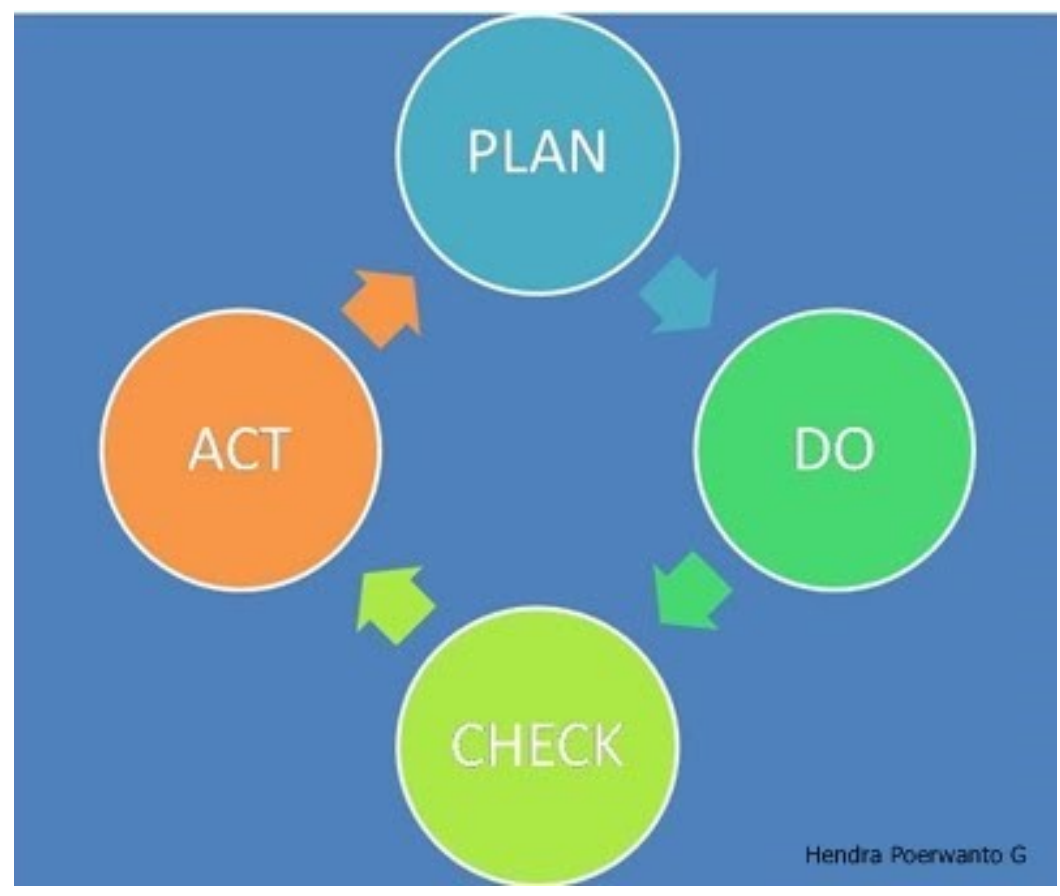

Gambar 1 Konsep PDAC

Konsep P-D-C-A merupakan proses untuk penyelesaian dan pengendalian suatu masalah dengan pola model secara berurutan dan tersistematis. Lebih jelasnya model PDCA dapat dijelaskan seperti berikut:

1. $\mathrm{P}($ Plan $=$ Rencanakan $)$

Tahapan pertama disini merencanakan tujuan (goal) apa saja proses yang dibutuhkan dalam menentukan hasil yang diharapkan dengan spesifikasi tujuan yang telah ditetapkan. Tahapan ini tujuan yang ingin dicapai adalah membuat pemodelan karakter 3D.

2. $\mathrm{D}($ Do $=$ Kerjakan $)$

Tahapan ke-dua yaitu perencanaan proses yang sudah ditentukan sebelumnya, batasanbatasan proses ini juga sidah ditetapkan dalam tahap sebelumnya yaitu perencanaan. Pada tahapan ini dihindari penundaan suatu pekerjaan, mulai dari koordinasi dengan pihak sekolah, pesrta yang akan mengikuti, pembuatan materi, persiapan laboratorium komputer, media daring yang digunakan, dan pelaksanaan kegiatan secara daring.

3. $\mathrm{C}($ Check $=$ Evaluasi $)$

Tahapan ke-tiga melakukan evaluasi terhadap tujuan dan prosesnya serta melaporkan apa saja hasilnya. Mengecek kembali apa yang telah dilakukan dari tahap awal sampai akhir, sudahkah sesuai dengan standar yang ditetapkan ataukah terdapat kekurangan. Tahapan ini memantau hasil karya setiap materi yang diberikan kemudian diberikan saran dan pendampingan untuk perbaikan hasil yang lebih baik.

4. A (Act $=$ Menindaklanjuti) 
Tahapan ke-empat melakukan evaluasi keseluruhan dari hasil tujuan, proses dan selanutnya menindaklanjuti dengan melakukan perbaikan-perbaikan. jika apa yang sudah dilakukan masih ada kekurangan atau belum sempurna, segeralah dilakukan tindakan untuk perbaikan. Tahapan ini sangat penting sebelum terlanjur melangkah lebih jauh ke dalam proses perbaikan selanjutnya.

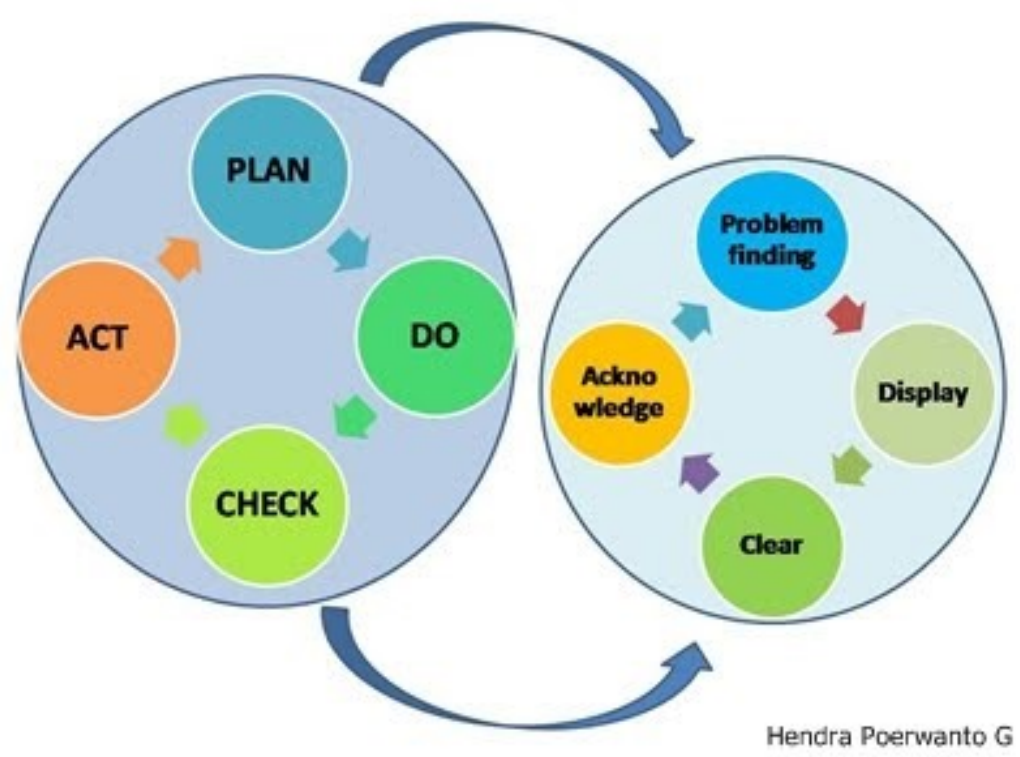

Gambar 2 Konsep PDCA dan Siklusnya

Gambar 2 menjelaskan bahwa hasil dari tahapan-tahapan model proses PDCA kemudian digunakan sebagai acuan bagi pelaksaaan proses perencanaan selanjutnya. Ke-empat proses yaitu Plan-Do-Check-Act (PDCA) merupakan raangkaian kesatuan siklus yang tidak dapat diputus dan satu dengan yang lain saling berhubungan.

\section{HASIL DAN PEMBAHASAN}

Hasil dari kegiatan pelatihan dan pendampingan kegiatan meningkatkan keahlian modelling character 3D bagi para guru dan siswa di lingkungan Sekolah Menengah Kejuruan (SMK) ST. Fransikus Semarang berdasarkan konsep PDCA.

\subsection{Perencanaan}

Pada tahapan ini melakukan sosialisai ke SMK, penentuan tujuan dan pengumpulan bahan serta mempelajari dan menanyakan modelling character 3D yang sudah berjalan dan mengamati kekurangan apa saja yang ada selama ini. Menyusun waktu pelaksanaan sesuai dengan target materi yang akan disampaikan dan kesepakatan dengan pihak sekolah dilakukan selama 5 kali pertemuan melalui media zoom meeting. Materi yang akan disampaikan terbagi ke dalam 5 materi yaitu : materi 1 : pengenalan software Blender dan kelengkapannya, materi 2 : pemodelan karakter 1 , materi 3 : pemodelan karakter 2, materi 4 : pemodelan karakter 3, dan materi 5 : proyek pemodelan $3 \mathrm{D}$. 
Abdimasku, Vol. 4, No. 3, September 2021: 228-238

Tabel 1. Rencana Pelaksanaan Kegiatan

\begin{tabular}{|c|c|c|c|c|}
\hline Waktu & Kegiatan & Tempat & $\begin{array}{c}\text { Penanggung } \\
\text { Jawab }\end{array}$ & Keterangan \\
\hline \multicolumn{5}{|c|}{ Hari I (17 November 2020) } \\
\hline $\begin{array}{l}08.00- \\
09.00\end{array}$ & $\begin{array}{l}\text { Registrasi } \\
\text { Ulang Peserta } \\
\text { dan persiapan }\end{array}$ & $\begin{array}{l}\text { Ruang Lab. Multimedia } \\
\text { SMK ST. FRANSISKUS } \\
\text { Semarang (Zoom Meet) }\end{array}$ & Tim pelaksana & $\begin{array}{l}\text { Mengisi daftar hadir } \\
\text { dan absensi peserta }\end{array}$ \\
\hline $\begin{array}{l}09.00- \\
10.00\end{array}$ & Pembukaan & $\begin{array}{l}\text { Ruang Lab. Multimedia } \\
\text { SMK ST. FRANSISKUS } \\
\text { Semarang } \\
\text { (Zoom Meet) }\end{array}$ & $\begin{aligned} & \text { 1. } \text { Kepala Sekolah } \\
& \text { SMK ST. } \\
& \text { 2. } \text { KRANSISKUS } \\
& \text { Ketua } \\
& \text { 3. }\end{aligned}$ & $\begin{array}{l}\text { 1. Y. Sudarna, S.Pd } \\
\text { 2. Muslih, M.Kom } \\
\text { 3. Stefani Deby, } \\
\text { S.Kom }\end{array}$ \\
\hline $\begin{array}{l}10.00- \\
12.00\end{array}$ & $\begin{array}{l}\text { Penyajian } \\
\text { Materi } 1\end{array}$ & $\begin{array}{l}\text { Ruang Lab. Multimedia } \\
\text { SMK ST. FRANSISKUS } \\
\text { Semarang } \\
\text { (Zoom Meet) }\end{array}$ & Tim Pelaksana & $\begin{array}{l}\text { Ali Muqodas, } \\
\text { M.Kom }\end{array}$ \\
\hline \multicolumn{5}{|c|}{ Hari 2 (18 November 2020) } \\
\hline $\begin{array}{l}08.00- \\
09.00\end{array}$ & $\begin{array}{l}\text { Paparan } \\
\text { Kemampuan } \\
\text { Teknis dan } \\
\text { peluang } \\
\text { Industri } \\
\end{array}$ & $\begin{array}{l}\text { Ruang Lab. Multimedia } \\
\text { SMK ST. FRANSISKUS } \\
\text { Semarang } \\
\text { (Google meet) }\end{array}$ & Tim pelaksana & Muslih, M.Kom \\
\hline $\begin{array}{l}09.00- \\
12.00\end{array}$ & $\begin{array}{l}\text { Penyajian } \\
\text { Materi } 2\end{array}$ & $\begin{array}{l}\text { Ruang Lab. Multimedia } \\
\text { SMK ST. FRANSISKUS } \\
\text { Semarang } \\
\text { (Google meet) }\end{array}$ & Tim Pelaksana & $\begin{array}{l}\text { Ali Muqodas, } \\
\text { M.Kom }\end{array}$ \\
\hline \multicolumn{5}{|c|}{ Hari 3 (19 November 2020) } \\
\hline $\begin{array}{l}08.00- \\
09.00\end{array}$ & $\begin{array}{l}\text { Paparan } \\
\text { Kemampuan } \\
\text { Teknis dan } \\
\text { peluang } \\
\text { Industri } \\
\end{array}$ & $\begin{array}{l}\text { Ruang Lab. Multimedia } \\
\text { SMK ST. FRANSISKUS } \\
\text { Semarang } \\
\text { (Google meet) }\end{array}$ & Tim pelaksana & $\begin{array}{l}\text { Ali Muqodas, } \\
\text { M.Kom }\end{array}$ \\
\hline $\begin{array}{l}09.00- \\
12.00\end{array}$ & $\begin{array}{l}\text { Penyajian } \\
\text { Materi } 3\end{array}$ & $\begin{array}{l}\text { Ruang Lab. Multimedia } \\
\text { SMK ST. FRANSISKUS } \\
\text { Semarang } \\
\text { (Google meet dan } \\
\text { Channel YouTube) }\end{array}$ & Tim Pelaksana & Ajib Susanto, M.Kom \\
\hline \multicolumn{5}{|c|}{ Hari 4 (20 November 2020) } \\
\hline $\begin{array}{l}08.00- \\
09.00\end{array}$ & $\begin{array}{l}\text { Paparan } \\
\text { Kemampuan } \\
\text { Teknis dan } \\
\text { peluang } \\
\text { Industri } \\
\end{array}$ & $\begin{array}{l}\text { Ruang Lab. Multimedia } \\
\text { SMK ST. FRANSISKUS } \\
\text { Semarang }\end{array}$ & Tim pelaksana & $\begin{array}{l}\text { Elkaf Rahmawan P., } \\
\text { M.Kom }\end{array}$ \\
\hline $\begin{array}{l}09.00- \\
12.00\end{array}$ & $\begin{array}{l}\text { Penyajian } \\
\text { Materi } 4\end{array}$ & $\begin{array}{l}\text { Ruang Lab. Multimedia } \\
\text { SMK ST. FRANSISKUS } \\
\text { Semarang } \\
\text { (Google meet dan } \\
\text { Channel YouTube) }\end{array}$ & Tim Pelaksana & $\begin{array}{l}\text { Dr. M. Arief } \\
\text { Soeleman, M.Kom }\end{array}$ \\
\hline \multicolumn{5}{|c|}{ Hari 5 (21 November 2020) } \\
\hline $\begin{array}{l}08.00- \\
12.00\end{array}$ & $\begin{array}{l}\text { Pendampingan } \\
\text { Project }\end{array}$ & $\begin{array}{l}\text { Ruang Lab. Multimedia } \\
\text { SMK ST. FRANSISKUS } \\
\text { Semarang }\end{array}$ & Tim pelaksana & $\begin{array}{l}\text { Ali Muqodas, } \\
\text { M.Kom / Muslih, } \\
\text { M.Kom/ Elkaf } \\
\text { Rahmawan, M.Kom }\end{array}$ \\
\hline
\end{tabular}




\subsection{Kerjakan}

Pada tahap ini mulai melakukan kegiatan pelatihan dan pendampingan materi modelling character $3 D$, berikut ini hasil kegiatan pelatihan dan pendampingan.

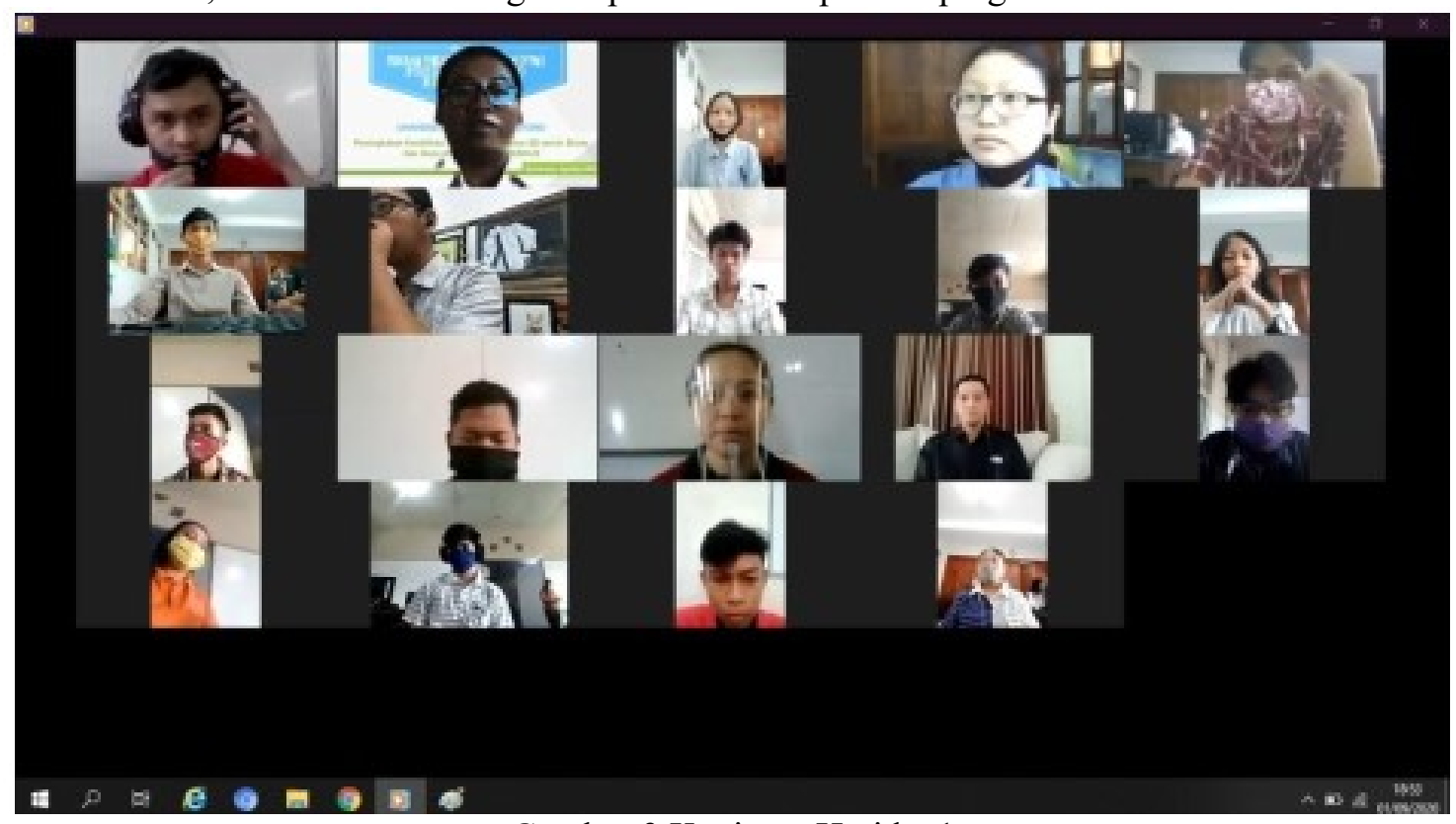

Gambar 3 Kegiatan Hari ke 1

Gambar 3 di atas menunjukkan pemateri dan peserta yang mengikuti kegiatan daring pelatihan, Gambar 4 berikut adalah pembukaan dari pelatihan :

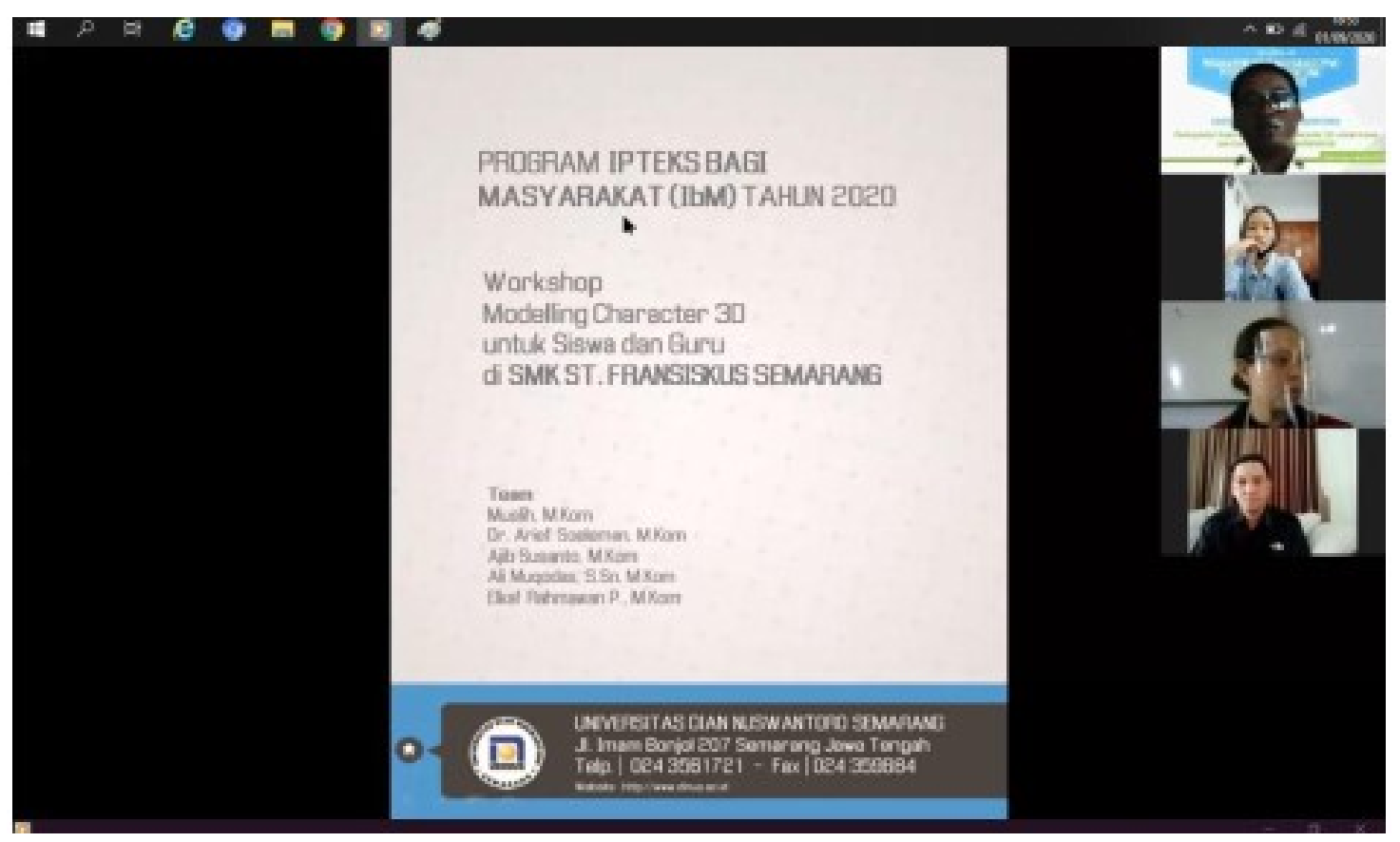

Gambar 4 Pembukaan Pelatihan dengan Zoom Meeting 


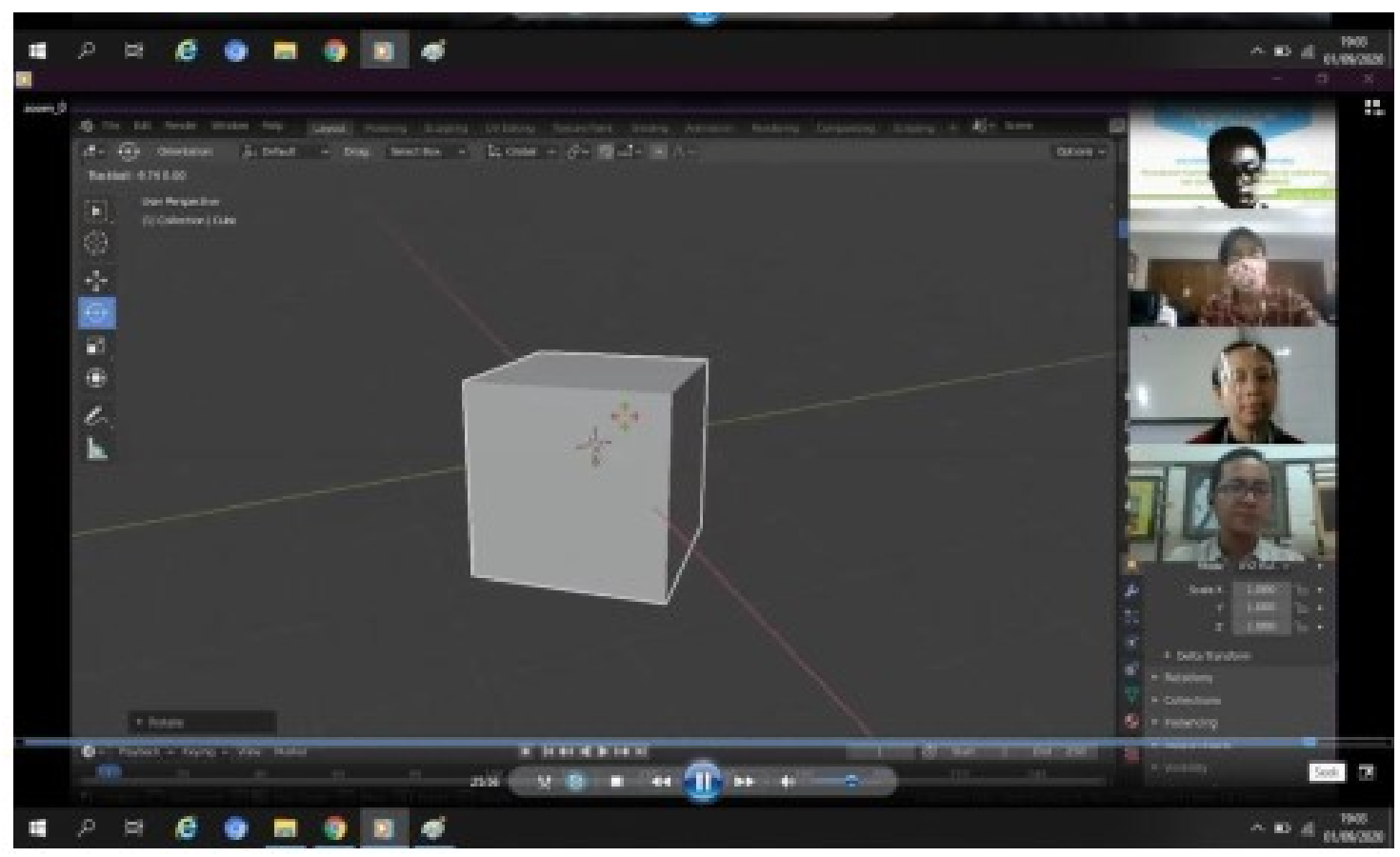

Gambar 5 Materi Modelling 3D

Gambar 5 adalah pemberian materi Modelling $3 D$ dengan menggunakan media daring, dilakukan secara langsung sehingga peserta juga langsung dapat mempraktekkan dan apabila ada kendala dapat langsung ditanyakan kepada pemateri.

\section{Editor - Video Sequencer}

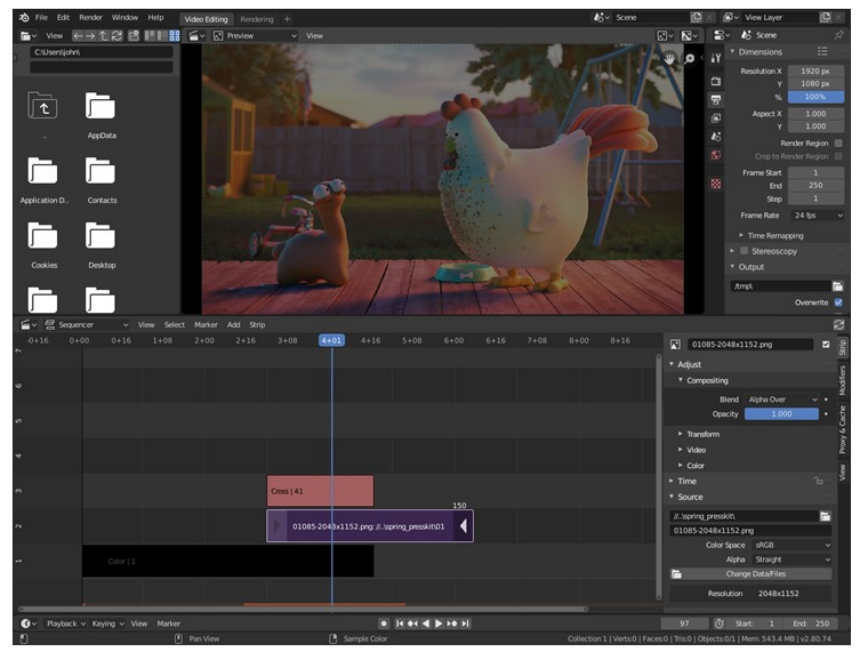

- Video Sequencer dalam Blender adalah sistem pengeditan video lengkap yang memungkinkan Anda menggabungkan beberapa saluran video dan menambahkan efek padanya.

\section{Gambar 6 Materi Editor - Video Sequencer}

Gambar 6 di atas adalah materi editing video yang digunakan untuk menggabungkan beberapa saluran video dan menambahkan efek di video sehingga menghasilkan karakter yang seuai dengan kebutuhan. 


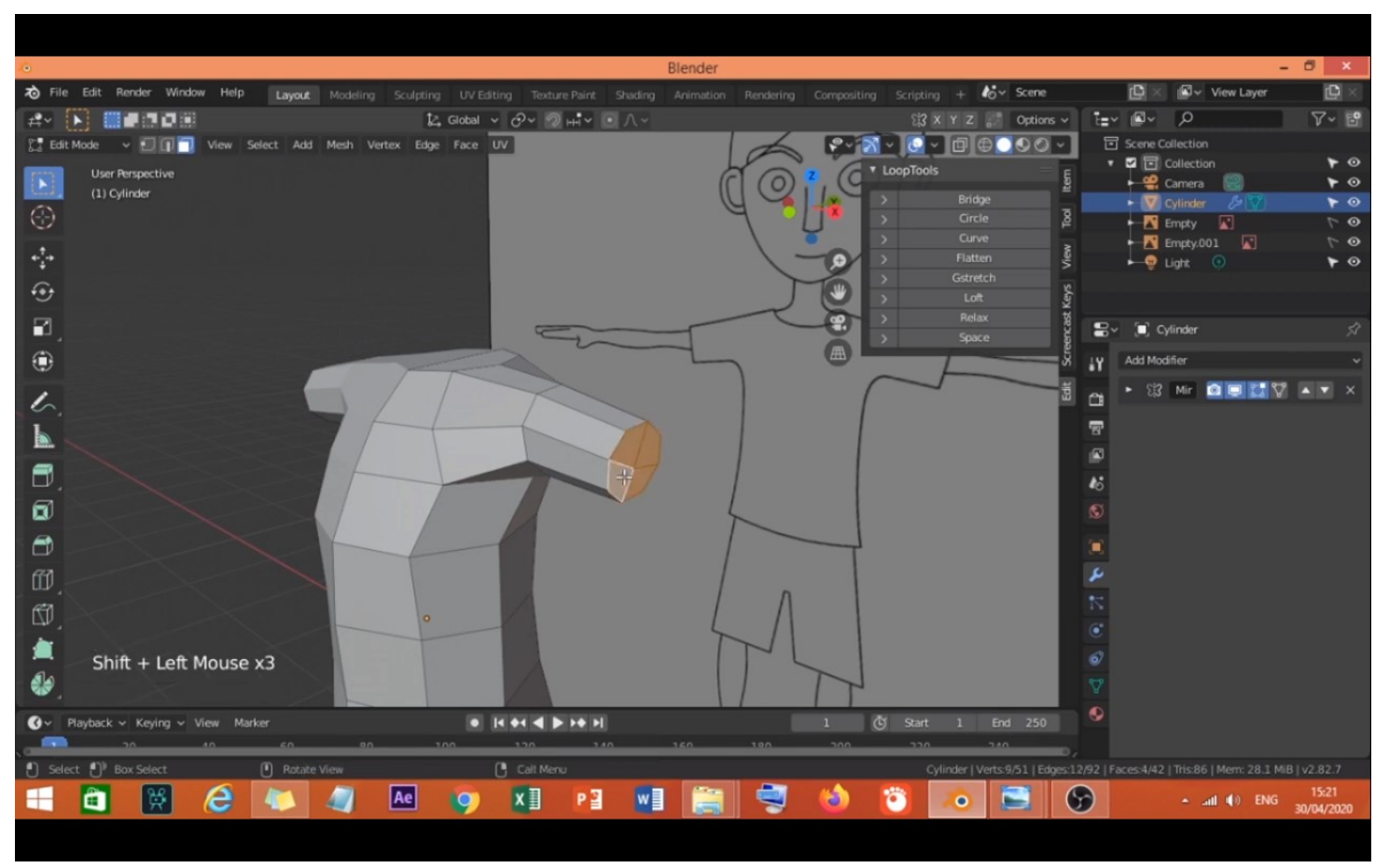

Gambar 7 Modelling gambar 2D menjadi 3D

Gambar 7 merupakan materi pelatihan untuk membuat karakter 3D dari gambar yang sudah disipakan kemudian diubah menjadi karakter modelling $3 D$ sehingga karakter yang dihasilkan lebih jelas dan lebih nyata.

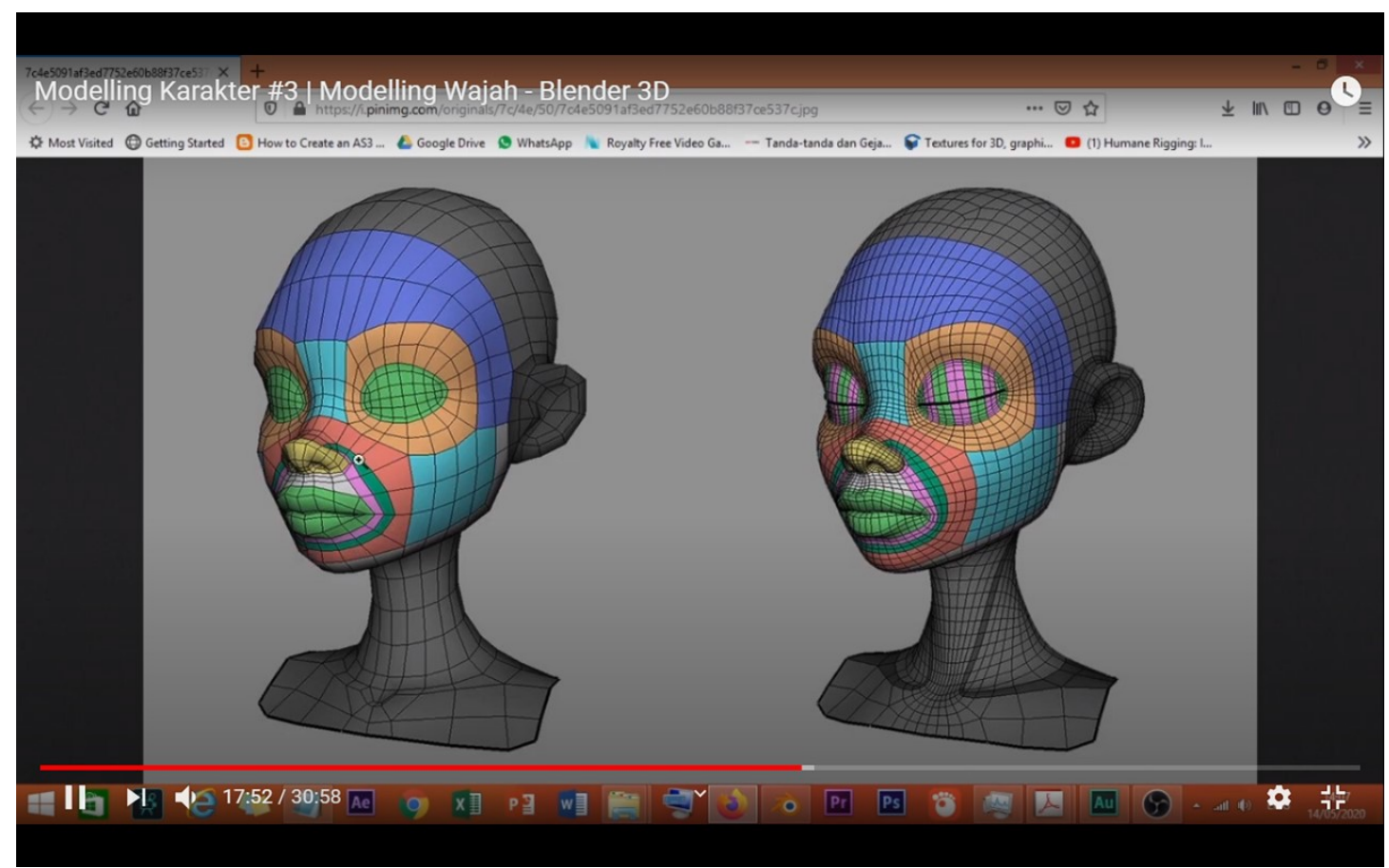

Gambar 8 Modelling Wajah

Sumber image : https://magazine.3dconceptart.com/2016/08/28/sergi-caballer-facial-modeling 


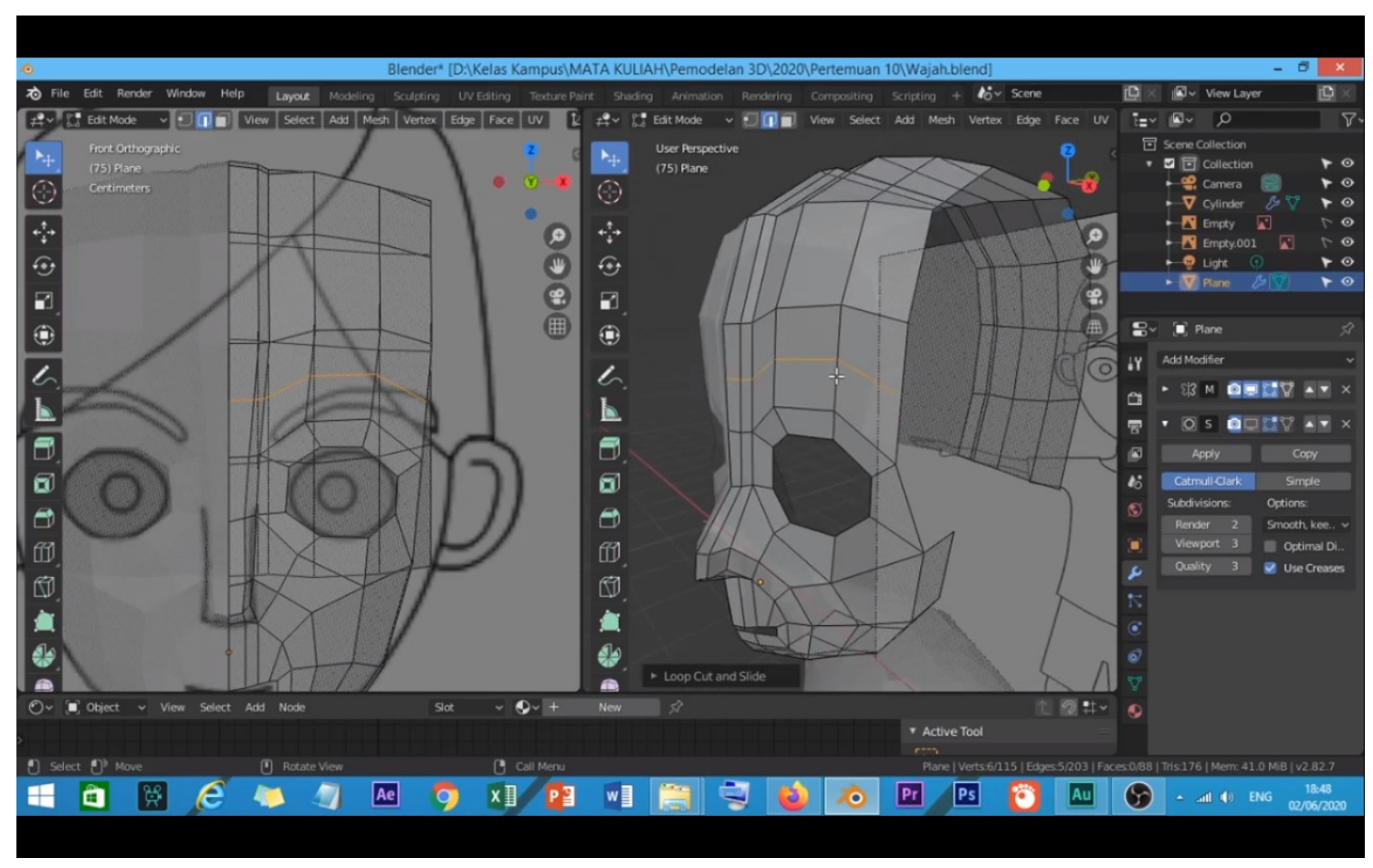

Gambar 9 Proses modelling wajah

Gambar 8 dan Gambar 9 adalah modelling wajah langkah demi langkah sesuai skenario yang dibuat sehingga wajah yang diinginkan dapat terealisasi dengan baik dan sesuai tujuan pembuatan modelling wajah untuk kebutuhan aplikasi selanjutnya.

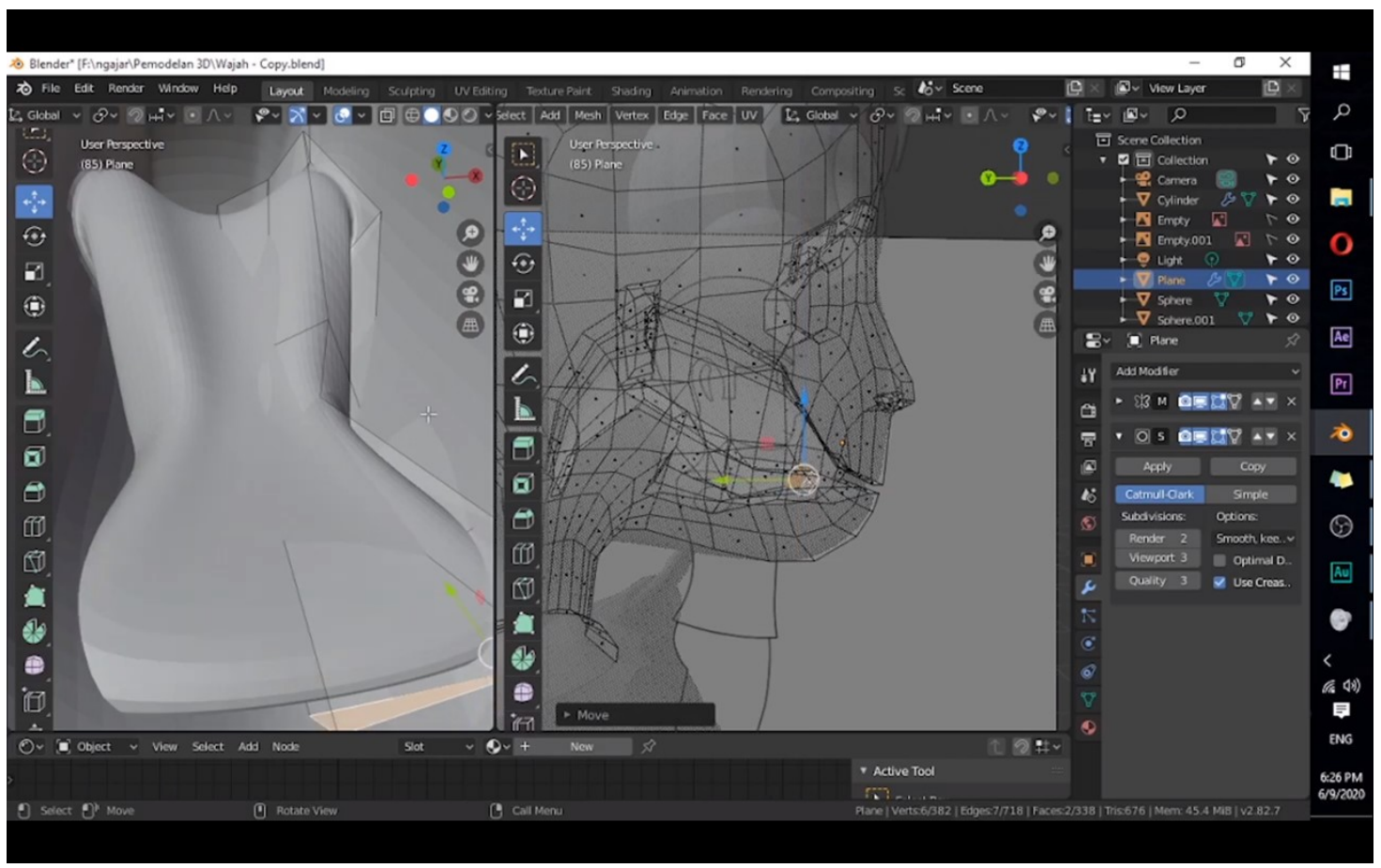

Gambar 10 Modelling badan

Gambar 10 merupakan materi kelanjutan setelah membuat modelling wajah yaitu materi 
modelling badan yang menghubungkan dengan modelling wajah, sehingga akan mendapatkan satu kesatuan karakter.

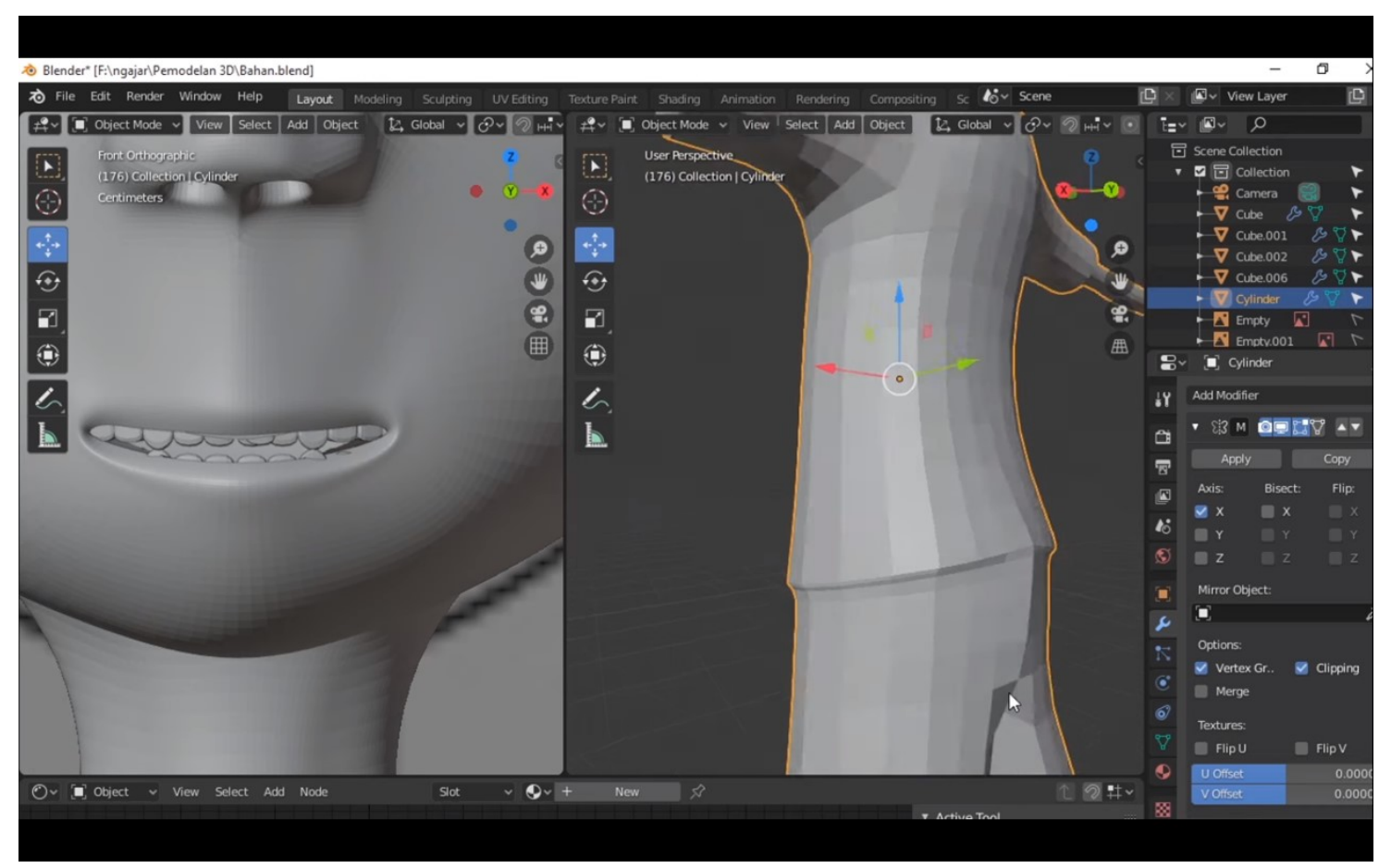

Gambar 11 Hasil modelling badan

Gambar 11 merupakan hasil pelatihan dari pemodelan badan secara menyeluruh, hasil keseluruhan modelling wajah dan badan dapat dimanfaatkan untuk kebutuhan pembuatan video dan game sehingga menghasilkan karakter yang nyata dan sesuai kebutuhan.

\subsection{Evaluasi}

Pada tahap ini dilakukan pemantauan hasil karya dari para peserta dan menentukan hal apa lagi yang dapat digunakan untuk terus meningkatkan kemampuan para peserta. Hal yang dikerjakan adalah :

a. Mengamati karya dan memberikan masukan perbaikan.

b. Mengamati proses pembuatan modelling character $3 D$ sudah memenuhi kaidah atau tujuan pembuatan karakter, jika belum sesuai diberikan masukan dan bila perlu diberikan tambahan materi keahlian untuk memperbaiki karya yang dihasilkan.

c. Menganalisa respon atau tanggapan peserta apakah cenderung positif atau negative sehingga dapat dirumuskan langkah untuk tindakan selanjutnya.

\subsection{Menindaklanjuti}

Pada tahap ini melakukan kegiatan sesuai yang direkomendasikan atau laporan perkembangan setelah dilakukan evaluasi sehingga sasaran yang hendap dicapai dapat diwujudkan. Memulai lagi untuk merencanakan, menganalisa dan menindaklanjuti yang telah disepakati sesuai dari hasil evaluasi yang dilakukan sebelumnya.

\section{KESIMPULAN DAN SARAN}

Dari hasil program IbM pelatihan siswa dan guru SMK ST. Fransiskus Semarang sudah dilaksanakan dengan baik dengan target dapat meningkatakan kemampuan siswa dan guru sebagai persiapan kelas XII dalam menghadapi UKK sebelum lulus dari jenjang SMK dengan 
kompetensi multimedia sehingga kemampuan yang didapat siswa dapat digunakan kelak ketika sudah masuk ke dunia kerja.

\section{UCAPAN TERIMA KASIH}

Penulis mengucapkan terima kasih kepada Lembaga Penelitian dan Pengabdian Masyarakat (LPPM) Universitas Dian Nuswantoro yang telah memberikan dukungan melalui pendanaan dalam kegiatan pengabdian ini.

\section{DAFTAR PUSTAKA}

[1] M. Putri, "Ini Harapan Ganjar Kepada Lulusan SMK di Jawa Tengah," Tribunjateng.com, 2019. [Online]. Available: https://jateng.tribunnews.com/2019/05/01/ini-harapan-ganjar-kepada-lulusan-smk-dijawa-tengah. [Accessed: 03-Apr-2020].

[2] I. Puspita, "Perkembangan Media Pembelajaran," Blogspot, 2012. [Online]. Available: http://indri220410.blogspot.com/2012/12/perkembangan-media-pembelajaran_21.html. [Accessed: 17-Apr-2020].

[3] N. Mamoon and G. Rasskin, "Covid-19," https://covidvisualizer.com/, 2020. [Online]. Available: https://covidvisualizer.com/. [Accessed: 17-Apr-2020].

[4] HarmoniPermata, "Perkembangan Animasi 3D dari Masa ke Masa," https://harmonipermata.com/perkembangan-animasi-3d-dari-masa-ke-masa/, 2020. [Online]. Available: https://harmonipermata.com/perkembangan-animasi-3d-dari-masake-masa/. [Accessed: 17-Apr-2020].

[5] Ngadi, "The Relevance of Vocational Education on Labor Market in Salatiga," $J$. Kependud. Indones., vol. 9, no. 1, pp. 59-70, 2014.

[6] A. W. Khurniawan, G. Erda, and M. A. Majid, "Profil Lulusan SMK Terhadap Tingkat Penyerapan Tenaga Kerja," Distribution, no. January, pp. 1-23, 2019.

[7] A. Susanto, "Prakerin SMK Bisa Harapan DUDI," pp. 1-26, 2019.

[8] T. Damarjati, "Uji Kompetensi Keahlian Tahun Pelajaran 2020/2021," 2021. [Online]. Available: http://smk.kemdikbud.go.id/konten/4821/uji-kompetensi-keahlian-tahunpelajaran-20202021.

[9] H. Poerwanto G, "Plan-Do-Check-Act (PDCA)," https://sites.google.com. [Online]. Available: https://sites.google.com/site/kelolakualitas/PDCA. [Accessed: 11-Oct-2019].

[10] A. Susanto, C. A. Sari, D. R. I. Moses, E. H. Rachmawanto, and I. Utomo, "Implementasi Facebook Marketplace untuk Produk UMKM sebagai Upaya Peningkatan Pemasaran dan Penjualan Online," J. Pengabdi. Masy. - LPPM Univ. Dian Nuswantoro Semarang, vol. 3, no. 1, pp. 42-51, 2020.

[11] I. U. Wahyu Mulyono, A. Susanto, E. H. Rachmawanto, C. A. Sari, and D. R. I. M. Setiadi, "Implementasi E-Learning Menggunakan Edmodo bagi Guru-Guru SD Kecamatan Cawas, Klaten,” vol. 3, no. 1, pp. 56-64, 2020. 